\title{
PREVALENCE OF HLA DQB1*0602 ALLELE IN PATIENTS WITH MIGRAINE
}

\author{
Fernando Morgadinho Santos Coelho', Márcia Pradella-Hallinan', \\ Paulo Corrêa Abud', Mario Predazzoli Neto', Fabio Moreira', \\ Lia Rita Azeredo Bittencourt', Mario Fernandes Pietro Peres ${ }^{3}$, Sérgio Tufik'
}

\begin{abstract}
Background: Studies have shown a high prevalence of migraine among narcoleptic patients. HLA-DQB1*0602 and HLA DRB1 alleles are closely associated with narcolepsy. An increase in the HLA-DRB1 allele frequency in patients with visual aura has raised greater awareness of the genetic background in migraine. Purpose: Since the regions DR and DQ of the HLA are in tightly linkage desiquilibrium we hypothesize that $\mathrm{HLA}-\mathrm{DQB}_{1}{ }^{*} 0602$ might be associated to the pathophysiology of migraine. Method: We analyzed the presence of $\mathrm{HLA} \mathrm{DQB}_{1}{ }^{0} 0602$ allele in 50 healthy subjects with no history of migraine, 53 patients with migraine without aura and 52 patients with migraine with aura. Results: There was no difference in the frequency of $\mathrm{HLA} \mathrm{DQB}^{*}{ }^{*} 0602$ allele when control subjects and all patients were compared. We failed to note any difference in frequencies when comparing migraine patients with and without aura. Conclusion: Further studies with different patient populations, with other hypothalamic markers (melatonin, hypocretin) in migraine patients may shed light on to its pathophysiology.
\end{abstract}

KEY WORDS: migraine, narcolepsy, $\mathrm{HLA} \mathrm{DQB}_{1}$ *0602 allele, genetics.

\begin{abstract}
Prevalência do alelo $\mathrm{HLA} \mathrm{DQB}{ }^{*} 0602$ em pacientes com enxaqueca
RESUMO - Contexto: Estudos têm demonstrado o aumento da prevalência de enxaqueca em pacientes com narcolepsia, um distúrbio de sono associado a um gene do sistema HLA, o alelo HLA-DQB1*0602. As regiões DQ e DR do HLA estão em alto desequilíbrio de ligação e já foi descrito um aumento da freqüência do alelo HLA DRB1 em pacientes com enxaqueca com aura visual, o que fortalece uma hipótese de herança genética para a enxaqueca. Objetivo: Nossa hipótese é que o alelo HLA-DQB1*0602 pode estar relacionado com a fisiopatologia da enxaqueca destes pacientes. Método: Nós analisamos a presença do alelo HLA$\mathrm{DQB} 1{ }^{*} 0602$ em 50 voluntários sadios sem história de enxaqueca, 53 pacientes com enxaqueca sem aura e 52 pacientes com aura. Resultados: Não houve diferença entre os controles sadios e os pacientes com enxaqueca. Não houve diferença entre os pacientes com enxaqueca com e sem aura. Conclusão: Futuros estudos com diferentes populações, com outros marcadores (melatonina e hipocretina) em pacientes com enxaqueca devem ser realizados para melhor esclarecimento de fisiopatologia.
\end{abstract}

PALAVRAS-CHAVE: enxaqueca, alelo HLA DQB1*0602, HLA, genética.

Migraine is a syndrome characterized by a moderate to severe, throbbing type headache, associated with photophobia, phonophobia, nausea and vomiting. It can be preceded by focal neurological symptoms named aura. It is a common condition, affecting about $6 \%$ of men and $20 \%$ of women in the general population, with high direct and indirect costs to patients, relatives and society at large $\mathrm{e}^{1}$. The pathophysiology of migraine has not been fully elucidated. The classical theory described by Moskowitz, which states that migraine is caused by a neuro-vascular inflam- matory reaction modulated by the trigeminal nerve is still accepted ${ }^{2-4}$. Other aspects including genetics, immune function, and the putative role of the hypothalamus in migraine pathophysiology have been documented ${ }^{5-7}$. A positive family history is common in migraine, usually found in patients with migraine with aura. An increase of the frequency of HLA-DRB1 allele in patients with visual aura has raised awareness of the genetic background of migraine ${ }^{8-9}$. The clinical associations of migraine with atopic diseases such as asthma, allergies, and eczemas have high-

'Psychobiology Department, Universidade Federal de São Paulo, São Paulo SP, Brazil; ${ }^{2}$ Alvorada Medical Center, São Miguel Paulista, São Paulo SP, Brazil. IInstitute of the Brain, Hospital Israelita Albert Einstein, São Paulo SP, Brazil. Support: AFIP \& FAPESP- CEPID 98/14303-3.

Received 16 January 2007, received in final form 13 September 2007. Accepted 4 October 2007.

Dr. Fernando Morgadinho Santos Coelho - Rua Marselhesa 500 / 14 andar - 04020-06o São Paulo SP - Brasil. E-mail: fernandomorgadinho@ hotmail.com 
lighted the immunological background of the syndrome $^{8}$. Recent emphasis has been given to the hypothalamus in headache disorders, particularly those with a close circadian or circannual biology, such as cluster headaches and trigemino-autonomic cephalalgias $^{9-12}$. But also in migraines ${ }^{11}$. Narcolepsy and migraine may be linked in several ways. Studies have shown a high prevalence of migraine among narcoleptic patients ${ }^{13}$. On the other hand, excessive daytime sleepiness is also found and is apparently not related to sleep apnea ${ }^{14}$.

The HLA-DQB1*0602 allele is closely associated with narcolepsy ${ }^{15}$. The HLA-DRB1 and $\mathrm{DQB}_{1}$ * regions are mapped to the short arm of the chromosome 6 and are in tightly linkage desiquilibrium. They are part of the class II Human Leukocyte Antigen (HLA) complex molecules, these molecules are proteins placed in cell membranes and bind to antigens forming the antigen-antibody complex. The antigen-antibody interaction is the triggering factor for both cell and antibody mediated immune reaction. Any alteration in the structure of these proteins, caused by changes in the sequence of bases of the DNA, can affect the affinity of the antigen binding thereby modifying the immune response ${ }^{15}$. Genetic polymorphisms are small alterations in the DNA sequence and are widespread in humans. Such alterations may be involved in some diseases as well as phenotypic expression. These modifications are also present in the HLA region and some of which are associated with several autoimmune diseases such as systemic lupus erythematosus, rheumatoid arthritis, and systemic sclerosis. Studies have associated HLA alleles with worsing prognosis and evolution of these diseases ${ }^{16-18}$.

Although environmental factors are important in the pathophysiology of these conditions, the increased frequency of the HLA-DQB $1{ }^{*} 0602$ in narcoleptic patients and the high number of narcoleptics with migraine must be considered in order to enhance our understanding of the mechanism of this disease. We hypothesized that $\mathrm{HLA}-\mathrm{DQB}_{1}$ *0602 might be related to migraine pathophysiology ${ }^{19-23}$.

Mindful of the above, the aim of the present study is to verify the frequency of the HLA-DQB1*0602 allele in migraine patients without sleep diseases.

\section{METHOD}

The local ethics committee (UNIFESP-EPM-number /2003) approved the study, all patients and controls gave written consent. Fifty healthy subjects with no history of migraine, fifty-three patients with migraine and fifty two patients with migraine with aura participated in this study.

All migraine patients with and without aura fulfilled the diagnostic criteria according to International Classification of Headache Disorders (IHS) ${ }^{24}$ and had more than fifteen headache episodes per month.

The control group subjects, migraine patients with and without aura were similar regarding age and sex (Table 1).

The migraine with aura group was composed by twentysix patients with visual aura (50\%), twenty-three (44\%) with visual and sensory aura and three $(6 \%)$ with sensory aura.

Control subjects and patients with personal or familial history of excessive daytime sleepiness according to Epworth Sleepiness Scale (ESS) ${ }^{25}$ score of 10 or higher were not included in the present study.

$H L A-D Q B 1 * 0602$ typing - DNA from these individuals was typed for DRB and DQB1 typed by the PCR-Allele Specific Amplification (PCR-ASA) method and DQA 1 by PCR followed by hybridization using Sequence Specific Oligonucleotides (PCR-SSO) ${ }^{25}$.

Statistical analysis - The Kolmogorov-Smirnov test was

Table 1. Sex and age.

\begin{tabular}{lccc}
\hline & $\begin{array}{c}\text { Healthy subjects } \\
(\mathrm{HS})\end{array}$ & $\begin{array}{c}\text { Patients without aura } \\
(\mathrm{PoA})\end{array}$ & $\begin{array}{c}\text { Patients with aura } \\
(\text { PwA })\end{array}$ \\
\hline Age (years) & $30.24 \pm 10.17$ & $31.66 \pm 8.34$ & $33.92 \pm 10.91$ \\
Sex & Male 11 & Male 7 & Male 6 \\
& Female 39 & Female 46 & Female 46 \\
\hline
\end{tabular}

Age (HS X PoA p=0.46; HS X PwA p=0.10; PoA X PwA p=0.23), t Student test; Sex (HS X PoA p=0.24; HS $X$ PwA $p=0.15$; PoA X PwA $p=0.79)$, Chi-square test.

Table 2. Prevalence of HLA DQ B1*0602 Allele.

\begin{tabular}{lccc}
\hline & $\begin{array}{c}\text { Healthy subjects } \\
(\mathrm{HS})\end{array}$ & $\begin{array}{c}\text { Patients without aura } \\
(\text { PoA })\end{array}$ & $\begin{array}{c}\text { Patients with aura } \\
\text { (PwA) }\end{array}$ \\
\hline Without HLA DQ B1*0602 Allele & 39 & 39 & 39 \\
With in at least HLA DQ B1*0602 Allele & 11 & 14 & 13 \\
\hline
\end{tabular}

(HS X PoA p=0.30), (HS X PwA p=0.39) and (PoA X PwA p=0.86). Chi-square test. 
used to check the homogeneity of variations and $t$ Student test was used for non-matched samples with values presented as mean and standard deviation. Furthermore the chi-square test was used to compare the frequencies of the HLA allele in the several groups studied. Statistical significance was set as $p<0.05$.

\section{RESULTS}

The presence of in at least the $\mathrm{DQB}_{1}{ }^{*} 0602$ allele in control subjects was $22 \%$ and in patients was $25 \%$, $\mathrm{p}=0.9$. The presence of in at least the $\mathrm{DQB}_{1}{ }^{*} 0602$ allele in migraine patients without aura was $25 \%$ and in patients with aura was $26 \%, p=0.9$. There was no difference in the frequency of in at least the $\mathrm{DQB}_{1}{ }^{*} 0602$ allele when compared control subjects and patients as a whole compared. We found no differences when comparing migraine patients with and without aura (Table 2).

\section{DISCUSSION}

The present study compared the frequencies of HLA-DQB $1 * 0602$ allele in control subjects, migraine patients with and without aura. The frequency of the HLA-DQB1*0602 allele was not difference among the groups studied.

Regarding the pathophysiology it is believed that the neuro anatomical region of the dysfunction in migraine as well as in narcolepsy is probably located in the brain stem ${ }^{11-13}$. Some neurotransmitters such as serotonin play an important role in the pathophysiology of both disorders. Hypocretins are neuropeptides produced in the lateral hypothalamus with a known role in narcolepsy ${ }^{24}$. Studies have shown that hypocretins interact with pain modulation pathways. A relationship between this neuropeptide with painful syndromes has been reported.

The frequency of HLA-DQB1*0602 allele in narcoleptics demonstrated that low hypocretins levels in cerebrospinal fluid is as high as $95 \%$. Immunological reactions are thought to be associated with self-destruction of the hypocretin producing cells of the lateral hypothalamus and subsequent hypocretin lower levels in hypocretin ${ }^{25-27}$.

Narcoleptics are more prone to migraine than non-narcoleptics and patients with migraine have experieced worsing pain when changes to sleep time are experieced ${ }^{8,28}$. The unaltered frequencies of the HLA-DQB1*0602 allele in migraine patients do not exclude a possible pathophysiologic correlation between migraine and narcolepsy. The presence of the HLA-DQB1*0602 allele is only part of complex and unknown pathophysiologic of the narcolepsy. Further studies with different patient populations, with other hypothalamic markers (melatonin, hypocretin) should be important to migraine and narcolepsy in patients and may shed light into pathophysiology.

\section{REFERENCES}

1. Silberstein DS, Lipton RB, Goadsby PJ. Headache in Clinical Practice. Oxford: ISIS, 1998

2. Buzzi MG, Moskowitz MA. The antimigraine drug, sumatriptan (GR43175), selectively blocks neurogenic plasma extravasation from blood vessels in dura mater. Br J Pharmacol 1990;99:202-206.

3. Levite M. Neuropeptides, by direct interaction with T cells, induce cytokine secretion and break the commitment to a distinct $\mathrm{T}$ helper phenotype. Proc Natl Acad Sci USA 1998;95:12544-12549.

4. Bolay H, Reuter U, Dunn AK, Huang Z, Boas DA, Moskowitz MA. Intrinsic brain activity triggers trigeminal meningeal afferents in a migraine model. Nat Med 2002;8:136-142.

5. O'Neill BP, Kapur JJ, Good AE. HLA antigens in migraine. Headache 1979;19:71-73.

6. Kudrow L. HL-A antigens in cluster headache and classical migraine. Headache 1978;18:167-168.

7. Martelletti P, Romiti A, Gallo MF, et al. HLA-B14 antigen in cluster headache. Headache 1984;24:152-154.

8. Rainero I, Fasano E, Rubino E, et al. Association between migraine and HLA-DRB1 gene polymorphisms J Headache Pain 2005;6:185-187.

9. Rainero I, Dall'Omo AM, Rubino E, et al. HLA-DRB1 genotyping in Italian migraine patients. Neurosci Lett 2006;393:90-93.

10. Kemper RH, Meijler WJ, Korf J, Ter Horst GJ. Migraine and function of the immune system: a meta-analysis of clinical literature published between 1966 and 1999. Cephalalgia 2001;21:549-557.

11. Peres MF. Melatonin, the pineal gland and their implications for headache disorders. Cephalalgia 2005;25:403-411.

12. Peres MF, Sanchez del Rio M, Seabra ML, et al. Primary headaches in obese patients. Arq Neuropsiquiatr 2005;63:931-933.

13. Peres MF, Sanchez del Rio M, Seabra ML, et al. Hypothalamic involvement chronic migraine. J Neurol Neurosurg Psychiatry 2001;71:747-751.

14. Peres MF, Stiles MA, Siow HC, Silberstein SD. Hypothalamic involvement in chronic migraine. J Neurol Neurosurg Psychiatry 2005; 76:1467-1468.

15. The DMKG Study Group. Migraine and idiopathic narcolepsy-a case control-study. Cephalalgia 2003;23:789-799.

16. Dahmen N, Kasten M, Wieczorek S, Gencik M, Epplen JT, Ullrich B. Increased frequency of migraine in narcoleptic patients. Cephalalgia 2003;1:14-19.

17. Peakman M., Vergani D. Basic and clinical Immunology. 1.Ed. London: Churchill Livingstone, 1999.

18. Wagner U, Kaltenhäuser S, Pierer M, Wilke B, Arnold S, Häntzschel H. B lymphocytopenia in rheumatoid arthritis is associated with the DRB1 shared epitope and increased acute phase response. Arthritis Res 2002; 4:R1.

19. Corcione A, Casazza S, Ferretti E, et al. Recapitulation of B cell differentiation in the central nervous system of patients with multiple sclerosis. Immunology 2004;101:11604-11609.

20. Sato S, Fujimoto M, Hasegawa M, Takehara K, Tedeer TF. Altered B lymphocyte function induces systemic autoimminity systemic sclerosis. Mol Immunol 2004;41:1123-1133.

21. Gallai V, Sarchielli P, Floridi A, Franceschini M, Trequattrini A, Firenze C. Monocyte function in migraine patients with and without aura. Headache Q 1994;5:214-227.

22. Munno I, Marinaro M, Bassi A, Cassiano MA, Causarano V, Centonze V. Immunological aspects in migraine: increase of IL-10 plasma levels during attack. Headache 2001;41:764-767.

23. Rainero I, Grimaldi LM, Salani G, et al. Association between the tumor necrosis factor-alpha $-308 \mathrm{G} / \mathrm{A}$ gene polymorphism and migraine. Neurology 2004;62:141-143.

24. Olsen J. The International Classification of headache disorders, 2.Ed.: application to practice. Department of Neurology, University of Copenhagen, Glostrup Hospital, Ndr. Ringvej 57, DK-2600 Glostrup, Denmark.2004.

25. Mignot E, Hayduk R, Black J, Grumet FC, Guilleminault C. HLA DQB $1{ }^{*} 0602$ is associated with cataplexy in 509 narcoleptic patients. Sleep 1997; 20:1012-1020.

26. Johns MW. New method for measuring daytime sleepiness: the Epworth Sleepiness Scale. Sleep 1991;14:540-545.

27. Van Den Pol AN. Hypothalamic hypocretin (orexin): robust innervation of the spinal cord. J. Neurosci 1999;19:3171-3177.

28. Kelman L. The triggers or precipitants of the acute migraine attack. Cephalalgia 2007;27:394-402. 